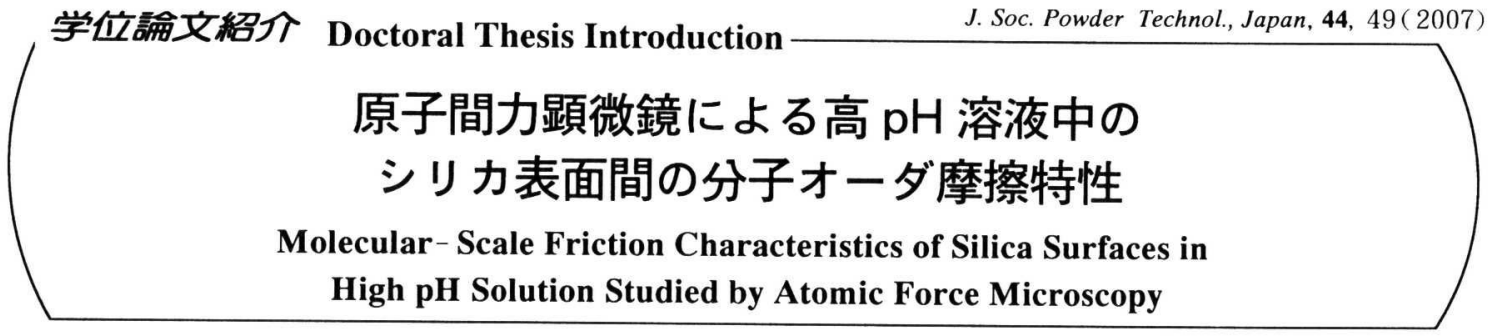

シリコンウエハーの超平坦化技術 (Chemical Mechanical Polishing: CMP) は電子デバイスの性能 を決定する重要な技術である。CMPではシリカ等の 研磨粒子とウエハーとの摩擦により平坦化されるとさ れており，表面の凹凸は 丹オーダにまで達している か，その基礎的メカニズムは殆ど分かっていない。本 研究では, 実際の CMP で行われる高 $\mathrm{pH}$ 領域での, ウエハー表面とシリカ粒子の摩摖力に関する基礎的理 解を得ることを目的とし, 原子間力顕微鏡 (AFM) にシリカコロイドプローブを取り付け, 種々の条件下 で, 高 $\mathrm{pH}$ 溶液中の摩擦力が何に依存しているかを分 子オーダで明らかにしたものである。

シリコンコンウエハーとシリカコロイドプローブの 表面を接触角が 0 度になるまで, ウエハー洗浄法とし て知られている RCA 法を主に用いて不純物を除去 し,ほぼ完全に親水化された表面に対し, 高 $\mathrm{pH}$ 領域 での垂直相互作用力と摩擦力を種々の条件下で測定 し，その分子オーダのメカニズムを推定した。

RCA 洗浄法で洗浄された表面は, マクロな值であ る接触角測定では完全に親水性であっても, 反応温度 が 50- $90^{\circ} \mathrm{C}$ まで変わると, 摩摖力は 2 倍程度まで明 確に変化すること, 並びにそれは, RMSで $1 \mathrm{~A}$ 以 下, 最大の高低差でも約 $1 \mathrm{~A}$ の表面疎度の違いで生じ ることを明らかにした。

摩擦力の $\mathrm{pH}$ 依存性については, 垂直相互作用力に 対しては, $\mathrm{pH}$ の増加と共に表面基の解離のため増加 し, pH8.6以上では一定になる。しかし, 逆に摩擦 力は, pH8.6 以上では低下し, $\mathrm{pH} 10.6$ では約 $1 / 10$ まで低下することを明らかにした。これは，摩擦力は 表面荷電には鈍感であるが表面構造には極めて敏感で あることを示している。

\section{Elena Taran}

"P. Poni" Institute of Macromolecular Chemistry, Iasi, Romania

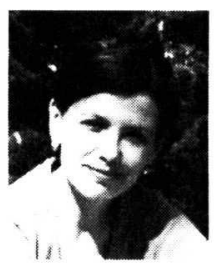

〈著者紹介>

June 2001 B. Sc., Chemical Engineering, "Gh. Asachi" Technical University, Iasi, Romania; June 2002 M. Sc., "Gh. Asachi" Technical University, Iasi, Romania; September $2006 \mathrm{PhD}$, Chemical Engineering, Kyoto Uni-versity, Japan; November 2006 Research Associate, Institute of Macromolecular Chemistry "P. Poni", Iasi. Romania.
しかし, 垂直印加力を極めて大きくすると, 摩擦力 は非線形に大きくなる。非常に大きい印加力では $\mathrm{pH}$ 5.6 の摩擦力上り大きくなり, その場合, スティクー スリップ現象が起こっていることを明らかにした。ま た, 垂直相互作用力を動的測定法で測定し, pH5.6で はゲル層, pH10.6 では Hairy 層が存在することを推 定した。以上の結果から, 低印加力領域では, Hairy 層に存在する豊富な水分子が摩擦力を低下させるが, 高印加力領域では, Hairy 層が互いに絡み合って, 摩摖力を增加させることが推定された。

$\mathrm{pH} 10.6$ の溶液に電解質を添加すると, $\mathrm{pH} 5.6$ の場 合とは大きく異なる現象が現れた。即ち, $\mathrm{Na}^{+}, \mathrm{K}^{+}$, $\mathrm{Cs}^{+}$では, 種類, 濃度によらず余り大きく変化しない か， $\mathrm{Li}^{+}$の場合は，その濃度の増加と共に大きく，ま た複雑に変化した。これは 2 価の $\mathrm{Ba}^{2+}, \mathrm{Mg}^{2+}$ と同様 の傾向であることから，Li が両表面の Hairy 層バイ ンダーの役目をしているものと推定された。

Acknowledgements : I would like to express my gratitude to my advisor, Professor Ko Higashitani, for his encouragement, support and guidance throughout my $\mathrm{PhD}$ course. His teachings and expertise have allowed me to grow as a professional and also as a person. I am grateful for all the years in which he shared his vast knowledge with me.

\section{List of Publications}

1) Taran, E., et al., "Nonlinear friction characteristics between silica surfaces in high pH solution", Journal of Colloid Interface Science, in press.

2 ) Taran, E., et al., "pH dependence of friction forces between silica surfaces in solutions", Journal of Colloid Interface Science 2006, 297, 199-203.

3) Taran, E., et al., "Effects of cleaning procedure of silica wafers on their friction properties", Journal of Colloid Interface Science 2006, 299, 233-237.

4) Taran, E., et al., “ATRP grafting of styrene from benzyl chloride functionalized polysiloxanes: An AFM and TGA study of the $\mathrm{Cu}(0) /$ bpy catalyst.", European Polymer Journal 2006, 42, 119- 125

5 ) Taran, E., et al., "Specific effects of divalent cation nitrates on the nanotribology of silica surfaces", Industrial and Engineering Chemistry Research, 2006, vol 46, 7035- 7041

6 ) Taran, E., et al., "Atom-transfer-radical-polymerization 1. Investigation of the catalytic system based on $\mathrm{Cu}(0)$ and 2, $2^{\prime}$-bipyridyl", I. P. I. Bulletin, 2004, 50. $45-47$.

(学位取得は 2006 年 11 月, 京都大学) 


\title{
学位論丈紹介 Doctoral Thesis Introduction
}

\section{異形粒子塗膜の充填構造に基づく浸透・透過機構の 解析亡その電池電極への応用}

\author{
Analysis of Penetration and Permeation Mechanisms Based on Packing Structure \\ of Cast Film with Different Particle Shape and Application to Battery Electrode
}

\section{1. 研究の目的}

電池には，高エネルギー密度化，高出力化および長 期信頼性が要求され，そのためには正極および負極の 電極構造の最適化が重要である。各電極は反応面積を 大きくするために，粒子状の活物質から構成される場 合が多く，粒子の大きさや形状，電極の厚さや空孔率 亡電池性能の関係の検討が必要となる。

そこで本論文では，大然鱗片状黒鉛の黒鉛化度が高 いという特長を生かし，高性能なリチウムイオン電池 の負極活物質を得るために，(1)粒子形状の調整方法， (2)塗膜内の粒子のミクロな充填構造の解析, (3)天然黒 鉛からの負極用黑鉛粉末の調製，(4)塗膜の構造之液体 の浸透性および透過性の関係, (5)粒子形状がリチウム イオン電池の負極特性におよぼす効果について検討し た。

\section{2. 主な研究成果}

まず，方式の異なる 2 種類の形状調整装置を用いて 天然黒鉛粒子の形状調整を実施し，それらのローター 周速および処理時間の増加に伴って近似楕円の短長軸 比である形状指数が高くなり, 球状化が進行した。高 速回転衝撃法は，形状調整之同時に粒子径を変化させ る効果があり，一方の摩砕式形状調整法は，粒子径を ほとんど変化させずに形状調整できるが，表面の結晶 性の乱れを表すラマン分光の R 值は, 処理時間の増加 に伴って直線的に增大することが分かった。

次に異形黒鉛粒子を用いて塗膜を調製し，調製条件 による塗膜厚さと構造の変化をマクロとミクロの視点 で検討した結果, 塗布速度の効果と比較して, 粒子形 状による効果は大きく，薄片状粒子と球状粒子では大 きな違いを生じた。また，形状が球に近い粒子で作製 した塗膜のメディアン空孔徍は大きく，限界充填密度 が高い広い空孔径分布の充填構造をとることを明らか にした。

さらに，人造および天然黒鉛を用いて作製した塗膜 について，液の浸透速度と透過性を測定した結果，浸 透速度は，主として塗膜の空孔径分布によって決定さ れ，空隙率が大きく，大きなメディアン空孔径を有す る塗膜ほど速いことを確認した。黒鉛塗膜の透過性の 測定値は，不均一円管モデルを用いて記述することか

大関克知 (Katsutomo Ohzeki)

日立粉末冶金株式会社 機能製品事業部開発部

（テ289-2247 千葉県香取郡多古町水戸1番地）TEL 0479-76-5571 Development Departure Fine Materials \& Component

Division, Hitachi Powdered Metals Co., Ltd

(1. Mito, Tako-machi, Katori-gun, Chiba 289-2247, Japan)

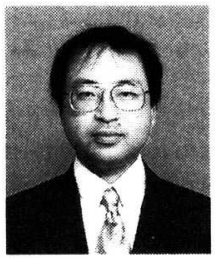

<著者紹介>

1990年 3 月東海大学大学院 理学研究科 化 学専攻卒業同年, 日立粉末治金株式会社に入 社し現在に至る。

専門：化学工学, 粉体工学
でき，黒鉛粒子が球状化するに従って，屈曲度が小さ くなり透過性が良好になることを明らかにした。ま た，粒子形状が球状になるにしたがってタッピング充 填密度が高く，そのような黒鉛粉末を用いた塗膜の最 頻度空隙径はプレス後も大きいことが分かった。そし て，塗膜の最頻度空隙径が大きくなるほど，負極の高 速放電特性は向上し，不可逆容量も低下した。多ッヒ ング充填密度の高い黒鉛で作製した電極は，低い充填 密度では粒子同士が点接触であり，その結果，充放電 の繰り返しによって粒子間の接触が不安定になり，電 気抵抗が上昇して充放電容量は低下した。しかし，塗 膜内の粒子充填密度を高くし，粒子間の接触を高めて 電気抵抗を低減することで，充放電サイクルによる充 放電容量の低下を抑制できることが分かった。

\section{3. 今後の展開}

本研究の結果，黒鉛粒子形状と塗膜構造の関係を明 らかにし，充放電特性への効果を確認したことによ り, リチウムイオン電池の負極のみならず他の電池電 極の性能向上への展開が期待される。

最後に，本研究の遂行ならびに本論文の作成に当た り，終始格別なるご指導とご教示を賜りました北海道 大学篠原邦夫名誉教授に深甚なる感謝の意を表します とともに, 北海道大学微粒子工学研究室の皆様に心よ り感謝申し上げます。

\section{文献リスト}

1 ) Ohzeki, K., Y. Ohsaki, B. Golman and K. Shinohara : "Influence of void size distribution of anode film made of natural graphite particles on high rate discharge capability of lithium-ion battery", TANSO, 213, $140-143(2004)$

2 ) Seino, K., B. Golman, K. Shinohara and K. Ohzeki : "Variation of packing structure of cast film with pre paration conditions and particle properties", TANSO, 216, 2 - 7 (2005)

3) Ohzeki, K., B. Golman and K. Shinohara : "Shape and surface modification of natural graphite particles by mechano-chemical method", TANSO, 217, 99103 (2005)

4 ) Golman, B., T. Takigawa, K. Shinohara and K. Ohzeki : "Kinetics of liquid penetration into bottom edge of cast tape", Colloid and Surfaces $\boldsymbol{A}$ : Physicochemical and Engineering Aspects, 254, 9-16 (2005)

5 ) Ohzeki, K., Y. Saito, B. Golman and K. Shinohara "Shape modification of graphite particles by rota tional impact blending" Carbon, 43, 1673-1679 (2005)

6 ) Ohzeki, K., K. Seino, T. Kumagai, B. Golman and K. Shinohara: "Characterization of packing structure of tape cast with non-spherical natural graphite particles", Carbon, 44, 578-586 (2006)

7 ) Golman, B., K. Shinohara and K. Ohzeki : "Liquid permeation through cast tape of graphite particles based on non-uniform packing structuren", Journal of Power Sources, 159, 328-331 (2006)

8 ) Ohzeki, K., Y. Ohsaki, B. Golman and K. Shinohara "Charge and discharge cycle performance of negative electrode film of lithium ion battery made of natural graphite particles of different tapping densities", TANSO, 221, 19-24 (2006)

(学位取得は 2006 年 3 月，北海道大学) 